\title{
Diversity and composition of tiger moths (Lepidoptera: Arctiidae) in an area of Atlantic Forest in southern Brazil: is the fauna more diverse in the grassland or in the forest?
}

\author{
Viviane Gianluppi Ferro ${ }^{1,3}$ \& Helena Piccoli Romanowski²
}

\author{
${ }^{1}$ Departamento de Ecologia, Instituto de Ciências Biológicas, Universidade Federal de Goiás. Caixa Postal 131, \\ 74001-970 Goiânia, GO, Brazil. \\ 2 Departamento de Zoologia, Instituto de Biociências, Universidade Federal do Rio Grande do Sul. Avenida Bento Gonçalves \\ 9500, Bloco IV, Prédio 43435, 91501 -970 Porto Alegre, RS, Brazil. \\ ${ }^{3}$ Corresponding author. E-mail: vgferro@yahoo.com
}

\begin{abstract}
The Atlantic Forest is considered a biodiversity hotspot for conservation, because its fauna and flora are highly endemic and suffer from loss of natural habitats. This study assessed the composition and diversity of tiger moths (Lepidoptera: Arctiidae) in two floristic formations of the southern Atlantic Forest (grassland and Araucaria forest) and in a transition zone (forest edge). The moths were attracted to UV light reflected onto a white sheet. A total of 3,574 tiger moths were collected, representing 121 species. The rarefaction curves showed that the tiger-moth assemblage collected in the grassland was more diverse than the assemblages from the Araucaria forest and the transition zone. The assemblages in the forest and forest edge resembled each other, whereas the grassland assemblage was distinct. The composition of the tiger-moth assemblages was related to the environmental characteristics [habitat type (grassland, edge, or forest), altitude, temperature, air relative humidity] and the location of the sites. The faunal similarity decreased in response to increasing environmental and geographical distances between the sites. The responsiveness of tiger moths to small-scale variation in environmental and geographical parameters indicates their good potential as environmental indicators.
\end{abstract}

KEY WORDS. Araucaria forest; Arctiinae; beta-diversity; Lithosiinae

The tiger moths comprise a large group, with almost 11,000 described species (HePpNer 1991), 2,000 of which probably occur in Brazil (estimate of Brown \& Freitas 1999). Tiger moths are divided into three subfamilies: Arctiinae, Lithosiinae, and Syntominae (JACOBSON \& WeLLer 2002). Studies on the betadiversity of tiger moth were mainly conducted between 20002010 (e.g., Kitching et al. 2000, Hilt \& Fiedler 2005, 2006, Ferro $\&$ TEsTon 2009). The majority of those studies showed that tiger moths respond to gradients in the vegetation. Arctiid abundance is higher in scrubland sites than in primary and secondary forest sites (e.g., Kitching et al. 2000). Arctiid species diversity is significantly higher in early and late successional habitats than in the forest understory (Hilt \& Fiedler 2005), and relatively poor in abandoned pastures (HiLt \& Fiedler 2006). However, the type of response to successional/disturbance stages differs among arctiid subfamilies or tribes. For example, members of Phaegopterini (with more host-generalist larvae) were found to benefit from habitat disturbance, whereas Ctenuchini (with more host-specialist larvae) were more closely associated with undisturbed forest habitats (Hilt \& FiedLer 2006).
The Atlantic Forest originally occupied an area of 1.3 million $\mathrm{km}^{2}$ but has now been reduced to approximately $7 \%$ of its original size, and the remaining forest continues to be under severe anthropogenic pressure (Morelato \& HADDAD 2000). The biome is considered a biodiversity hotspot for conservation because of the high level of endemism of the flora and fauna, and the loss of natural habitats (MYers et al. 2000). The Atlantic Forest is characterized by a wide range of conditions, including latitudinal (from 6 to $30^{\circ} \mathrm{S}$ ), altitudinal (from zero to $2,900 \mathrm{~m}$ ), climatic (from tropical to subtropical, with annual rainfall from 1,000 to 4,000 $\mathrm{mm}$ ), and edaphic (soil types and depths) (Oliveira-Filho \& Fontes 2000). The floristic composition is also extremely heterogeneous, ranging from dense coastal forests, mangroves, restingas (coastal forests and scrub on sandy soil), inland deciduous and semideciduous forests, brejos (humid forests resulting from orographic rainfall in otherwise semidesert scrub habitat in northeast Brazil), high-elevation grasslands, and araucaria forests (Araucaria pine and Lauraceae-dominated forest) (Oliveira-Filho \& Fontes 2000, TABARELLI et al. 2005). 
The present study aimed to assess the richness, similarity, and composition of the tiger moth fauna in two Atlantic Forest vegetation formations (grassland and Araucaria forest) and in the zone between them (hereafter referred to as edge). We expected a higher richness in the Araucaria forest than in the grassland because wooded habitats are more heterogeneous than non-wooded habitats, and habitat heterogeneity and diversity are usually positively related (e.g., Tews et al. 2004). We also analyzed whether the beta-diversity pattern of these moths was more closely related to environmental or to geographical distances between the sampling sites.

\section{MATERIAL AND METHODS}

The study was carried out in the city of São José dos Ausentes (28 $\left.44^{\prime} 54^{\prime \prime} \mathrm{S}, 50^{\circ} 03^{\prime} 57^{\prime \prime} \mathrm{W}\right)$, northeastern Rio Grande do Sul (RS), the southernmost Brazilian state (Fig. 1). The annual mean temperature in the study area is $14.7^{\circ} \mathrm{C}$. The warmest months are January and February, with mean temperatures of approximately $19^{\circ} \mathrm{C}$. Altitudes range from 1,100 to $1,400 \mathrm{~m}$, and the annual mean rainfall is $1,726 \mathrm{~mm}$, with no dry season (Departamento Nacional de Meteorologia 1992). The study area is part of the Atlantic Forest biome. Mosaics of grassland and Araucaria forest characterize the landscape.

We selected 12 sites in the grassland area, 12 in the Araucaria forest, and five in the edge. However, one of the grassland sites was excluded from the analyses because no moths were collected, and the resulting total was 28 sites. The sites were sampled during one (if more than 40 individuals were collected) or two nights (if fewer than 40 individuals were collected on the first night), totaling 47 sampling nights. The de- tails and locations of the sites are given in Table I and Figure 2. Because the study area has long been used for cattle ranching, all sites showed some effects of the presence of cattle. However, the impacts of grazing were minor and were similarly distributed among all sites. The altitudes and geographical coordinates of the sampling sites were measured using a global positioning system. The temperature and air relative humidity were measured hourly during each sampling occasion, with a digital thermohygrometer positioned $1 \mathrm{~m}$ above the ground. For subsequent analyses, the temperature and air relative humidity readings were averaged over all sampling nights per site.

The tiger moths were attracted to a UV light ( $20 \mathrm{~W}$ tube, Sylvania Blacklight) set $1.5 \mathrm{~m}$ above the ground and reflected onto a $2 \mathrm{~m}$ high x $1.5 \mathrm{~m}$ wide white sheet. We also used a daylight tube with the same intensity, to aid the collector in observing the moths. We selected a battery-powered, low-intensity light in order to minimize the number of moths attracted from neighboring areas. The attraction radius of light traps described in the literature is variable, but most studies have shown that even much stronger light sources than those used in this study attract moths from a radius of 10-25 m (MuirHEAD-THomson 1991). Specimens were collected by hand using ammonia-loaded killing jars. During the summer of 2007 (January, February, and December) and the summer of 2008 (February and March), sampling was carried out from sunset to midnight, and was restricted to moonless periods (Yela \& Holyoak 1997).

All specimens were mounted and identified using digital images made by the first author from specimens deposited in the Private Collection of Vitor Becker, and from available descriptions and illustrations (HAMPSON 1898, 1900, 1901, 1914, Watson \& Goodger 1986, Piñas Rubio et al. 2000, Piñas Rubio \&
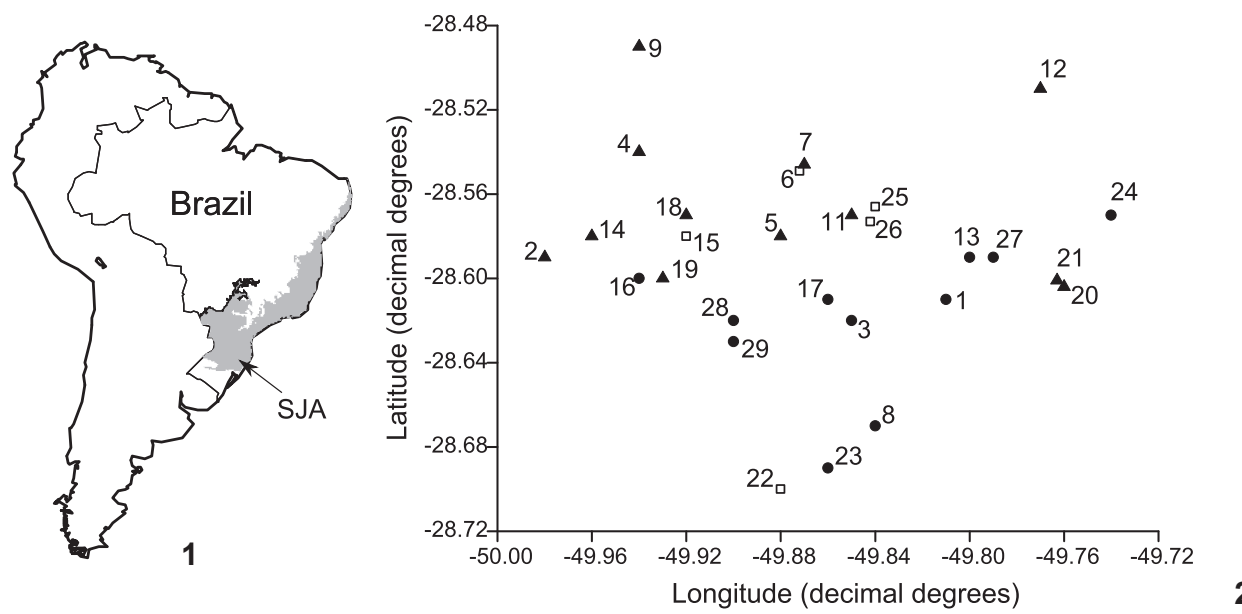

Figures 1-2. (1) Location of the study area. A arrow indicates São José dos Ausentes city (SJA) $\left(28^{\circ} 44^{\prime} 54^{\prime \prime} S, 50^{\circ} 03^{\prime} 57^{\prime \prime}\right.$ W), Brazil. The gray area corresponds to the original distribution of the Atlantic Forest biome. (2) Spatial distribution of the sampling sites. Circles indicate grassland sites, triangles indicate forest sites, and squares indicate edge sites. The numbers of the sites are shown. Grassland site number 10 was excluded from the study because no moths were collected.

ZOOLOGIA 29 (1): 7-18, February, 2012 
Table I. Geographical coordinates, altitude, vegetation type, mean temperature, mean relative humidity, species richness, abundance, and dominance of tiger moths at each sampling site. São José dos Ausentes, southern Brazil. Summers 2007-8.

\begin{tabular}{|c|c|c|c|c|c|c|c|c|}
\hline $\begin{array}{c}\text { Site } \\
\text { number* }\end{array}$ & Coordinates & $\begin{array}{l}\text { Altitude } \\
(\mathrm{m})\end{array}$ & Vegetation & $\begin{array}{c}\text { Temperature } \\
\left({ }^{\circ} \mathrm{C}\right)\end{array}$ & $\begin{array}{c}\text { Relative humidity } \\
(\%)\end{array}$ & Richness & Abundance & $\begin{array}{c}\text { Dominance } \\
\text { (Simpson index) } \\
\end{array}$ \\
\hline 1 & $28^{\circ} 36^{\prime} 52^{\prime \prime} \mathrm{S}, 49^{\circ} 48^{\prime} 51^{\prime \prime} \mathrm{W}$ & 1260 & grassland & 16.5 & 87.7 & 11 & 25 & 0.1584 \\
\hline 2 & $28^{\circ} 35^{\prime} 18^{\prime \prime} \mathrm{S}, 49^{\circ} 58^{\prime} 32^{\prime \prime} \mathrm{W}$ & 1217 & forest & 18.1 & 90.6 & 24 & 126 & 0.1120 \\
\hline 3 & $29^{\circ} 37^{\prime} 11^{\prime \prime} \mathrm{S}, 49^{\circ} 51^{\prime} 10^{\prime \prime} \mathrm{W}$ & 1205 & grassland & 15.2 & 92.3 & 13 & 25 & 0.1200 \\
\hline 4 & $28^{\circ} 32^{\prime} 07^{\prime \prime} \mathrm{S}, 49^{\circ} 56^{\prime} 21^{\prime \prime} \mathrm{W}$ & 1253 & forest & 18.8 & 87.5 & 27 & 165 & 0.0984 \\
\hline 5 & $28^{\circ} 34^{\prime} 36^{\prime \prime} \mathrm{S}, 49^{\circ} 52^{\prime} 41^{\prime \prime} \mathrm{W}$ & 1178 & forest & 13.8 & 91.2 & 42 & 188 & 0.1051 \\
\hline 6 & $28^{\circ} 32^{\prime} 58^{\prime \prime} \mathrm{S}, 49^{\circ} 52^{\prime} 22^{\prime \prime} \mathrm{W}$ & 1131 & edge & 12.9 & 88.3 & 39 & 266 & 0.1433 \\
\hline 7 & $28^{\circ} 32^{\prime} 47^{\prime \prime} S, 49^{\circ} 52^{\prime} 18^{\prime \prime} \mathrm{W}$ & 1184 & forest & 16.1 & 92.0 & 33 & 136 & 0.0707 \\
\hline 8 & $28^{\circ} 40^{\prime} 07^{\prime \prime} \mathrm{S}, 49^{\circ} 50^{\prime} 32^{\prime \prime} \mathrm{W}$ & 1307 & grassland & 17.8 & 96.3 & 3 & 8 & 0.5937 \\
\hline 9 & $28^{\circ} 29^{\prime} 39^{\prime \prime} \mathrm{S}, 49^{\circ} 56^{\prime} 18^{\prime \prime} \mathrm{W}$ & 1263 & forest & 15.8 & 92.2 & 46 & 330 & 0.1012 \\
\hline 11 & $28^{\circ} 34^{\prime} 30^{\prime \prime} \mathrm{S}, 49^{\circ} 50^{\prime} 54^{\prime \prime} \mathrm{W}$ & 1210 & forest & 13.8 & 86.8 & 24 & 130 & 0.1395 \\
\hline 12 & $28^{\circ} 30^{\prime} 49^{\prime \prime} \mathrm{S}, 49^{\circ} 46^{\prime} 20^{\prime \prime} \mathrm{W}$ & 1184 & forest & 19.2 & 88.3 & 13 & 45 & 0.2485 \\
\hline 13 & $28^{\circ} 35^{\prime} 28^{\prime \prime} \mathrm{S}, 49^{\circ} 48^{\prime} 05^{\prime \prime} \mathrm{W}$ & 1244 & grassland & 15.1 & 87.9 & 16 & 182 & 0.7385 \\
\hline 14 & $28^{\circ} 35^{\prime} 02^{\prime \prime} \mathrm{S}, 49^{\circ} 57^{\prime} 19^{\prime \prime} \mathrm{W}$ & 1270 & forest & 14.0 & 86.7 & 27 & 152 & 0.1800 \\
\hline 15 & $28^{\circ} 34^{\prime} 34^{\prime \prime} \mathrm{S}, 49^{\circ} 55^{\prime} 12^{\prime \prime} \mathrm{W}$ & 1250 & edge & 13.8 & 90.5 & 35 & 163 & 0.1122 \\
\hline 16 & $28^{\circ} 35^{\prime} 55^{\prime \prime} \mathrm{S}, 49^{\circ} 56^{\prime} 10^{\prime \prime} \mathrm{W}$ & 1164 & grassland & 14.4 & 84.2 & 3 & 3 & 0.3333 \\
\hline 17 & $28^{\circ} 36^{\prime} 19^{\prime \prime} \mathrm{S}, 49^{\circ} 51^{\prime} 44^{\prime \prime} \mathrm{W}$ & 1198 & grassland & 12.1 & 85.7 & 9 & 24 & 0.2431 \\
\hline 18 & $28^{\circ} 34^{\prime} 26^{\prime \prime} \mathrm{S}, 49^{\circ} 55^{\prime} 29^{\prime \prime} \mathrm{W}$ & 1300 & forest & 13.4 & 88.5 & 34 & 272 & 0.1249 \\
\hline 19 & $28^{\circ} 35^{\prime} 48^{\prime \prime} \mathrm{S}, 49^{\circ} 55^{\prime} 37^{\prime \prime} \mathrm{W}$ & 1183 & forest & 13.7 & 85.5 & 15 & 54 & 0.1516 \\
\hline 20 & $28^{\circ} 36^{\prime} 06^{\prime \prime} \mathrm{S}, 49^{\circ} 45^{\prime} 46^{\prime \prime} \mathrm{W}$ & 1248 & forest & 13.2 & 78.8 & 32 & 184 & 0.1856 \\
\hline 21 & $28^{\circ} 36^{\prime} 15^{\prime \prime} \mathrm{S}, 49^{\circ} 45^{\prime} 44^{\prime \prime} \mathrm{W}$ & 1238 & forest & 13.1 & 85.7 & 28 & 129 & 0.2074 \\
\hline 22 & $28^{\circ} 41^{\prime} 59^{\prime \prime} \mathrm{S}, 49^{\circ} 52^{\prime} 55^{\prime \prime} \mathrm{W}$ & 1227 & edge & 14.1 & 88.0 & 22 & 46 & 0.0699 \\
\hline 23 & $28^{\circ} 41^{\prime} 34^{\prime \prime} \mathrm{S}, 49^{\circ} 51^{\prime} 31^{\prime \prime} \mathrm{W}$ & 1213 & grassland & 13.6 & 80.6 & 32 & 68 & 0.0683 \\
\hline 24 & $28^{\circ} 33^{\prime} 58^{\prime \prime} \mathrm{S}, 49^{\circ} 44^{\prime} 41^{\prime \prime} \mathrm{W}$ & 1133 & grassland & 13.0 & 90.4 & 11 & 56 & 0.3782 \\
\hline 25 & $28^{\circ} 34^{\prime} 23^{\prime \prime} \mathrm{S}, 49^{\circ} 50^{\prime} 35^{\prime \prime} \mathrm{W}$ & 1250 & edge & 17.1 & 80.5 & 47 & 413 & 0.1736 \\
\hline 26 & $28^{\circ} 33^{\prime} 59^{\prime \prime} \mathrm{S}, 49^{\circ} 50^{\prime} 31^{\prime \prime} \mathrm{W}$ & 1187 & edge & 16.4 & 86.2 & 41 & 255 & 0.1560 \\
\hline 27 & $28^{\circ} 35^{\prime} 36^{\prime \prime} \mathrm{S}, 49^{\circ} 47^{\prime} 23^{\prime \prime} \mathrm{W}$ & 1277 & grassland & 14.8 & 82.7 & 20 & 95 & 0.3270 \\
\hline 28 & $28^{\circ} 37^{\prime} 19^{\prime \prime} \mathrm{S}, 49^{\circ} 54^{\prime} 15^{\prime \prime} \mathrm{W}$ & 1180 & grassland & 13.4 & 80.5 & 11 & 15 & 0.1250 \\
\hline 29 & $28^{\circ} 37^{\prime} 30^{\prime \prime} \mathrm{S}, 49^{\circ} 53^{\prime} 50^{\prime \prime} \mathrm{W}$ & 1180 & grassland & 14.5 & 77.1 & 9 & 19 & 0.1634 \\
\hline
\end{tabular}

* Grassland site number 10 was excluded from the study because no moths were collected.

MANZANO 2003). Vouchers of all species collected in this study were deposited in the Coleção Zoológica of the Universidade Federal de Goiás (Goiânia).

We used non-parametric estimators (second-order Jackknife and Chao 2) to estimate the total tiger moth richness of the study area. Rarefaction was used to compare the richness among the habitats (grassland, edge, and Araucaria forest), as the sampling effort (taken as the number of individuals) differed between the habitats. The abundance and proportion of singletons were compared between habitats by ANOVA, and dominance (Simpson index) using Kruskal-Wallis tests.

The composition of the tiger moth assemblage was also assessed through multivariate analyses (Non-Metric Multidi- mensional Scaling - NMDS, and Unweighted Pair-Groups Method using arithmetic Averages - UPGMA). The Bray-Curtis index was used as the dissimilarity measure in these analyses. Partial Canonical Correspondence Analysis (pCCA) (Legendre et al. 2005) was used to assess whether the species composition of sites was related to spatial position or to environmental characteristics [habitat type (grassland, edge or forest), altitude, temperature, relative humidity]. Mantel tests were applied using the Spearman correlation coefficient and 1,000 permutations to assess the statistical significance between the faunal dissimilarity and the geographical and environmental matrices. Statistical analyses were performed using SYSTAT 9 (1998) and PAST (HAMmer et al. 2007) software. 


\section{RESULTS}

We collected 3,574 tiger moths from the two Neotropical subfamilies (Arctiinae and Lithosiinae), representing 121 species. Of these, $91(75 \%)$ were identified to the species level, $24(20 \%)$ to genus, and $6(5 \%)$ to subfamily. Of the identified species, 22 (18.2\%) were recorded for the first time from the state of Rio Grande do Sul (Tab. II). This proportion was higher (25.8\%) for Lithosiinae than for Arctiinae (15.5\%). The abundance and species richness for each site are presented in Table I, and the species are listed in Table II.

Second-order Jackknife estimated 180 species, indicating the occurrence of a minimum of 59 additional species in the sample area. The Chao 2 estimator produced a slightly lower value (162), suggesting 41 additional species. These analyses indicated that we collected between $67 \%$ (second-order Jackknife) and 74\% (Chao 2) of the estimated total species richness in the study area.

Ninety species belonged to the Arctiinae and 31 to the Lithosiinae. The most widespread species were Agylla sp. 1, Machadoia xanthosticta (Hampson, 1901) (both sampled at 22 sites), Cisthene triplaga Hampson, 1905 (20 sites), and Philoros rubriceps (Walker, 1854) (19 sites) (Tab. II). The abundance was highly variable among the sites, varying from three to 413 individuals (Tab. I). The most abundant species were $M$. xanthosticta (722 individuals), Agylla sp. 1 (534), C. triplaga (361), and Romualdia opharina (Schaus, 1921) (326). These four species together accounted for $54.4 \%$ of all individuals sampled.

When the variance was partitioned using pCCA, 33.8\% of the total variability was explained by the environmental and geographical matrices. The environmental matrix, alone, explained $19.5 \%$ of the total variability; the matrix of geographical coordinates explained $13.1 \%$; and only $1.2 \%$ of the variation was shared between the two matrices. This analysis suggested that both environmental characteristics and geographical distance influenced the beta diversity pattern of the tiger moths, and that habitat characteristics were slightly more important.

The correlations between tiger moth beta diversity and the environmental dissimilarity, and between tiger moth beta diversity and the geographical distances were positive in the Mantel tests $(r=0.71$ for habitat, $r=0.84$ for geographical distance, $p=0.001$ for both). This indicated that the faunal similarity decreased in response to increasing environmental dissimilarity and geographical distance among the sites.

\section{Differences among vegetation formations}

The total number of individuals collected was 520 in the grassland, 1,143 in the edge, and 1,911 in the forest (Tab. II). Mean abundance was significantly higher in the edge and forest (228 and 159 individuals, respectively) than in the grassland (47) $(\mathrm{F}=9.710$, d.f. $=2, \mathrm{p}<0.001)$. Dominance did not differ significantly among the vegetation formations $(\mathrm{H}=4.832$, d.f. $=2, \mathrm{p}=0.089$ ). In the grassland, the most abundant species was $M$. xanthosticta, totaling 254 individuals (49\% of the total abundance). In the edge and forest, the most abundant species were M. xanthosticta, Agylla sp. 1, C. triplaga, and R. opharina; these four species comprised $53.8 \%$ of all individuals collected in these two vegetation formations.

Forty percent of the species (49) were recorded from all three vegetation formations. The lowest proportion of species recorded in only one vegetation formation was obtained for the edge (eight species, 6.6\%); whereas in the forest and grassland, about $16 \%$ (20 and 19, respectively) of the species were recorded exclusively in each of these habitats. The number of species shared between the forest and edge (18) was more than four times higher than the number shared between the forest and grassland (four) and the edge and grassland (three). The mean proportion of singletons was significantly higher in the grassland $(63 \%)$ than in either the edge $(45 \%)$ or the forest $(44 \%)(\mathrm{F}=7.396$, d.f. $=2, \mathrm{p}=0.003)$.

The observed richness was 91 species in the forest, 78 in the edge, and 75 in the grassland (Tab. II). However, secondorder Jackknife estimated 143.1 species for the grassland, 107.6 for the edge, and 127.6 for the forest. Therefore, $52.4 \%$ of the estimated tiger moth fauna was collected in the grassland, $72.5 \%$ in the edge, and $71.3 \%$ in the forest. Similarly, the Chao 2 estimates were 143.1 for the grassland, 97.7 for the edge, and 114.4 for the forest, indicating that $52.4 \%$ of the estimated tiger moth fauna was recorded in the grassland, $79.8 \%$ in the edge, and $79.5 \%$ in the forest. Similarly to the results obtained with the species richness estimators, when differences in the sampling effort were corrected through rarefaction, the curves indicated that the grassland fauna was more diverse than the faunas from the other two vegetation formations (Fig. 3).

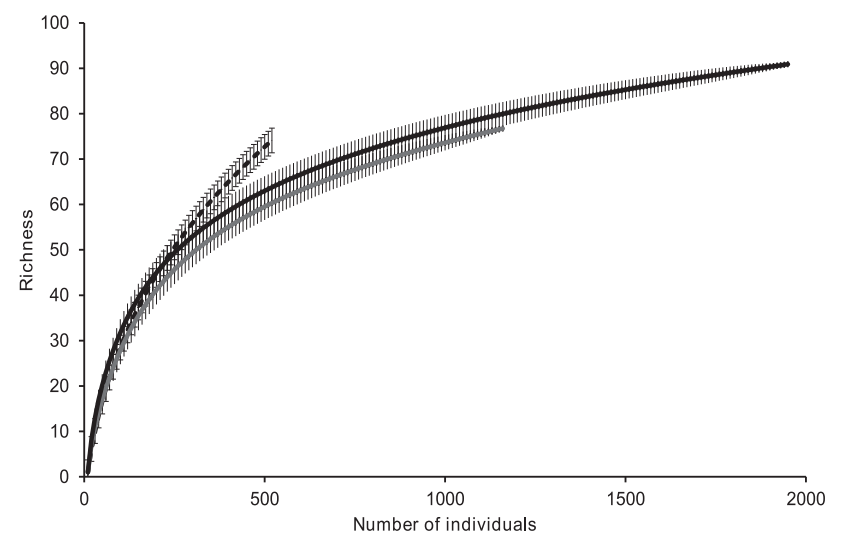

Figure 3. Rarefaction curves with the confidence limits for the three habitats sampled. Solid black line indicates forest, solid gray line indicates edge, and dotted line indicates grassland.

The forest and edge faunas appeared to be similar to each other (except for one edge site, which grouped with the grassland sites), whereas the grassland fauna was separated as a dis- 
Table II. List of tiger moths of São José dos Ausentes and their abundance in the three habitats.

\begin{tabular}{|c|c|c|c|c|}
\hline Moths species & Grassland & Edge & Forest & Total \\
\hline \multicolumn{5}{|l|}{ Arctiinae } \\
\hline Aclytia heber (Cramer, 1780) & 1 & 0 & 0 & 1 \\
\hline Aclytia terra Schaus, 1896 & 1 & 1 & 1 & 3 \\
\hline Aemilia pagana (Schaus, 1894) $\dagger$ & 2 & 0 & 0 & 2 \\
\hline Agaraea uniformis (Hampson, 1898) $\dagger$ & 0 & 1 & 3 & 4 \\
\hline Baritius acuminatus (Walker, 1865) & 4 & 3 & 1 & 8 \\
\hline Bertholdia almeidai Travassos, $1950 \dagger$ & 4 & 11 & 16 & 31 \\
\hline Biturix rectilinia (Burmeister, 1878) & 3 & 19 & 29 & 51 \\
\hline Carales maculifrons Walker, $1855 \dagger$ & 9 & 7 & 5 & 21 \\
\hline Cosmosoma centralis (Walker, 1854) & 13 & 14 & 10 & 37 \\
\hline Cosmosoma sp. 1 & 1 & 1 & 24 & 26 \\
\hline Ctenucha vittigera (Blanch, 1852) & 0 & 1 & 0 & 1 \\
\hline Cyanopepla jucunda (Walker, 1854) & 0 & 0 & 1 & 1 \\
\hline Cyanopepla sp. 1 & 0 & 0 & 2 & 2 \\
\hline Dysschema hilarina (Weymer, 1914) & 0 & 0 & 3 & 3 \\
\hline Dysschema lucifer (Butler, 1873) & 0 & 1 & 0 & 1 \\
\hline Dysschema luctuosum (Dognin, 1919) & 0 & 7 & 18 & 25 \\
\hline Dysschema trapeziata (Walker, 1865) & 0 & 0 & 1 & 1 \\
\hline Echeta minerva (Schaus, 1915) $\dagger$ & 1 & 0 & 0 & 1 \\
\hline Elysius intensa Rothschild, $1935 \dagger$ & 1 & 0 & 0 & 1 \\
\hline Elysius ordinarius (Schaus, 1894) & 1 & 5 & 10 & 16 \\
\hline Elysius pyrosticta Hampson, 1905 & 2 & 1 & 6 & 9 \\
\hline Episcepsis endodasia Hampson, 1898 & 1 & 0 & 0 & 1 \\
\hline Erruca hanga (Herrich-Schaeffer, [1854]) & 1 & 3 & 25 & 29 \\
\hline Eucereon apicalis (Walker, 1856) & 3 & 6 & 5 & 14 \\
\hline Eucereon ladas Schaus, 1892 & 2 & 6 & 39 & 47 \\
\hline Eucereon nubilosa Rothschild, $1912 \dagger$ & 1 & 1 & 0 & 2 \\
\hline Eucereon punctatum (Guérin, 1844) † & 1 & 0 & 0 & 1 \\
\hline Eucereon rosa (Walker, 1854) & 1 & 0 & 0 & 1 \\
\hline Eucereon striata (Druce, 1889) & 1 & 0 & 0 & 1 \\
\hline Euchaetes rizoma (Schaus, 1896) & 1 & 0 & 0 & 1 \\
\hline Eurota schausi Hampson, 1898 & 1 & 14 & 11 & 26 \\
\hline Galethalea pica (Walker, 1855) & 0 & 1 & 0 & 1 \\
\hline Halysidota pearsoni Watson, 1980 & 0 & 1 & 1 & 2 \\
\hline Halysidota striata Jones, 1908 & 8 & 34 & 73 & 115 \\
\hline Hemihyalea extincta Reich, $1935 \dagger$ & 1 & 2 & 34 & 37 \\
\hline Hypercompe sp. 1 & 2 & 2 & 3 & 7 \\
\hline Hypercompe sp. 2 & 1 & 0 & 0 & 1 \\
\hline Hypidalia enervis Schaus, 1894 & 2 & 3 & 7 & 12 \\
\hline Ichoria tricincta (Herrich-Schaeffer, [1855]) & 3 & 18 & 36 & 57 \\
\hline Idalus agastus Dyar, 1910 & 0 & 0 & 2 & 2 \\
\hline Idalus sp. 1 & 0 & 0 & 1 & 1 \\
\hline Ischnocampa lithosioides (Rothschild, 1912) † & 1 & 0 & 0 & 1 \\
\hline
\end{tabular}


Table II. Continued.

\begin{tabular}{|c|c|c|c|c|}
\hline Moths species & Grassland & Edge & Forest & Total \\
\hline Isia alcumena (Berg, 1882)† & 0 & 0 & 4 & 4 \\
\hline Ixylasia trogonoides (Walker, 1864) † & 0 & 1 & 0 & 1 \\
\hline Lepidolutzia baucia (Dalman, 1823) † & 1 & 0 & 0 & 1 \\
\hline Lepypiranga albiceps (Rothschild, 1933) † & 1 & 0 & 0 & 1 \\
\hline Leucanopsis citrina (Sepp, 1852) & 0 & 0 & 1 & 1 \\
\hline Leucanopsis dalipa (Jones, 1908) † & 1 & 2 & 10 & 13 \\
\hline Leucanopsis leucanina (Felder \& Rogenhofer, 1874) & 0 & 4 & 7 & 11 \\
\hline Leucanopsis oruba (Schaus, 1892) & 1 & 3 & 13 & 17 \\
\hline Leucanopsis pectina (Schaus, 1896) $\dagger$ & 2 & 13 & 28 & 43 \\
\hline Leucanopsis pulverea (Schaus, 1896) & 0 & 2 & 3 & 5 \\
\hline Leucanopsis romoloa (Schaus, 1933) & 7 & 8 & 18 & 33 \\
\hline Leucanopsis sp. 1 & 0 & 0 & 7 & 7 \\
\hline Leucanopsis sp. 2 & 0 & 2 & 3 & 5 \\
\hline Leucanopsis terola (Schaus, 1941) $\dagger$ & 0 & 4 & 7 & 11 \\
\hline Lophocampa ronda (Jones, 1908) † & 1 & 0 & 1 & 2 \\
\hline Lophocampa sp. 1 & 3 & 12 & 29 & 44 \\
\hline Machadoia xanthosticta (Hampson, 1901) & 254 & 277 & 187 & 718 \\
\hline Mazaeras francki Schaus, 1896 & 1 & 1 & 13 & 15 \\
\hline Mirandisca harpalyce (Schaus, 1892) & 0 & 0 & 1 & 1 \\
\hline Napata castra Hampson, 1898 & 0 & 0 & 1 & 1 \\
\hline Nelphe confinis (Herrich-Schaeffer, [1855]) & 1 & 0 & 0 & 1 \\
\hline Neritos repanda Walker, 1855 & 1 & 0 & 0 & 1 \\
\hline Opharus basalis Walker, 1856 & 0 & 1 & 0 & 1 \\
\hline Opharus procroides Walker, 1855 & 1 & 0 & 2 & 3 \\
\hline Opharus sp. 1 & 0 & 1 & 0 & 1 \\
\hline Paracles aurantiaca (Rothschild, 1910) $\dagger$ & 3 & 0 & 0 & 3 \\
\hline Paracles sp. 1 & 5 & 2 & 0 & 7 \\
\hline Paracles sp. 2 & 7 & 9 & 4 & 20 \\
\hline Pelochyta cinerea (Walker, 1855) & 25 & 10 & 10 & 45 \\
\hline Phaegoptera chorima Schaus, 1896 & 3 & 7 & 20 & 30 \\
\hline Phaegoptera granifera Schaus, $1892 \dagger$ & 2 & 6 & 80 & 88 \\
\hline Phaegoptera punctularis (Herrich-Schaeffer, [1855]) $\dagger$ & 4 & 10 & 13 & 27 \\
\hline Philoros rubriceps (Walker, 1854) & 14 & 15 & 48 & 77 \\
\hline Rhynchopyga meisteri (Berg, 1883) & 1 & 0 & 3 & 4 \\
\hline Romualdia opharina Schaus, $1921 \dagger$ & 9 & 77 & 240 & 326 \\
\hline Saurita sp. 1 & 0 & 0 & 1 & 1 \\
\hline Sphecosoma aenetus (Schaus, 1896) & 0 & 8 & 1 & 9 \\
\hline Symphlebia lophocampoides Felder, 1874 & 1 & 6 & 14 & 21 \\
\hline Symphlebia sp. 1 & 1 & 0 & 2 & 3 \\
\hline Symphlebia sp. 2 & 0 & 1 & 1 & 2 \\
\hline Symphlebia sp. 3 & 0 & 1 & 1 & 2 \\
\hline Symphlebia sp. 4 & 0 & 0 & 2 & 2 \\
\hline Tessella semivaria (Walker, 1856) & 0 & 3 & 5 & 8 \\
\hline
\end{tabular}


Table II. Continued.

\begin{tabular}{|c|c|c|c|c|}
\hline Moths species & Grassland & Edge & Forest & Total \\
\hline Tessella sertata (Berg, 1882) & 0 & 0 & 1 & 1 \\
\hline Theages leucophaea (Walker, 1855) & 0 & 0 & 1 & 1 \\
\hline Tipulodes ima Boisduval, 1832 & 0 & 0 & 1 & 1 \\
\hline Virbia fasciata Rothschild, $1910 \dagger$ & 1 & 12 & 17 & 30 \\
\hline Virbia ovata Rothschild, $1910 \dagger$ & 0 & 0 & 1 & 1 \\
\hline \multicolumn{5}{|l|}{ Lithosiinae } \\
\hline Agylla argentea (Felder, 1874) & 0 & 0 & 3 & 3 \\
\hline Agylla argentifera (Walker, 1866) † & 3 & 1 & 0 & 4 \\
\hline Agylla involuta (Hampson, 1900) $\dagger$ & 0 & 1 & 8 & 9 \\
\hline Agylla separata (Schaus, 1894) & 17 & 20 & 16 & 53 \\
\hline Agylla sp. 1 & 28 & 230 & 276 & 534 \\
\hline Agylla sp. 2 & 6 & 5 & 3 & 14 \\
\hline Agylla sp. 3 & 2 & 3 & 4 & 9 \\
\hline Agylla sp. 4 & 3 & 2 & 18 & 23 \\
\hline Agylla sp. 5 & 0 & 0 & 3 & 3 \\
\hline Agylla venosa (Schaus, 1894) $\dagger$ & 2 & 0 & 0 & 2 \\
\hline Cisthene calochroma (Snellen, 1878) $\dagger$ & 1 & 8 & 52 & 61 \\
\hline Cisthene ruficollis (Hübner, 1824) & 1 & 15 & 3 & 19 \\
\hline Cisthene triplaga Hampson, $1905 \dagger$ & 5 & 135 & 221 & 361 \\
\hline Dipaene incontenta Schaus, $1905 \dagger$ & 0 & 2 & 4 & 6 \\
\hline Eudesmia ruficollis Donovan, 1798 & 5 & 9 & 2 & 16 \\
\hline Eugonosia sp. 1 & 0 & 1 & 1 & 2 \\
\hline Euthyone grisescens (Schaus, 1911) $\dagger$ & 1 & 0 & 0 & 1 \\
\hline Euthyone purpurea (Jones, 1914) † & 2 & 5 & 21 & 28 \\
\hline Illice sp. 1 & 0 & 2 & 16 & 18 \\
\hline Illice sp. 2 & 1 & 15 & 69 & 85 \\
\hline Lamprostola olivacea (Schaus, 1896) $†$ & 1 & 5 & 8 & 14 \\
\hline Lycomorphodes suspecta (Felder, 1875) $†$ & 0 & 2 & 0 & 2 \\
\hline Metalobosia cuprea (Schaus, 1896) $\dagger$ & 0 & 0 & 2 & 2 \\
\hline NI 1 & 4 & 8 & 1 & 13 \\
\hline $\mathrm{NI} 2$ & 10 & 1 & 6 & 17 \\
\hline $\mathrm{NI} 3$ & 0 & 1 & 1 & 2 \\
\hline $\mathrm{NI} 4$ & 0 & 1 & 0 & 1 \\
\hline NI 5 & 0 & 6 & 19 & 25 \\
\hline $\mathrm{NI} 6$ & 0 & 0 & 1 & 1 \\
\hline Nodozana endoxantha Jones, $1908 \dagger$ & 2 & 27 & 25 & 54 \\
\hline Rhabdathomis mandana Dyar, 1907 & 1 & 0 & 0 & 1 \\
\hline Total abundance & 520 & 1143 & 1911 & 3574 \\
\hline Total species richness & 75 & 78 & 91 & 121 \\
\hline
\end{tabular}

$\dagger$ New record for the state of Rio Grande do Sul. $\mathrm{NI}=$ species not identified.

tinct group by the NMDS analysis (Fig. 4). The similarity among the grassland sites was lower than among the edge/forest sites. The UPGMA analysis (Fig. 5) corroborated the NMDS analysis.
All grassland sites (in addition to one edge and one forest site) were separated from the edge and forest sites in the first four divisions. 


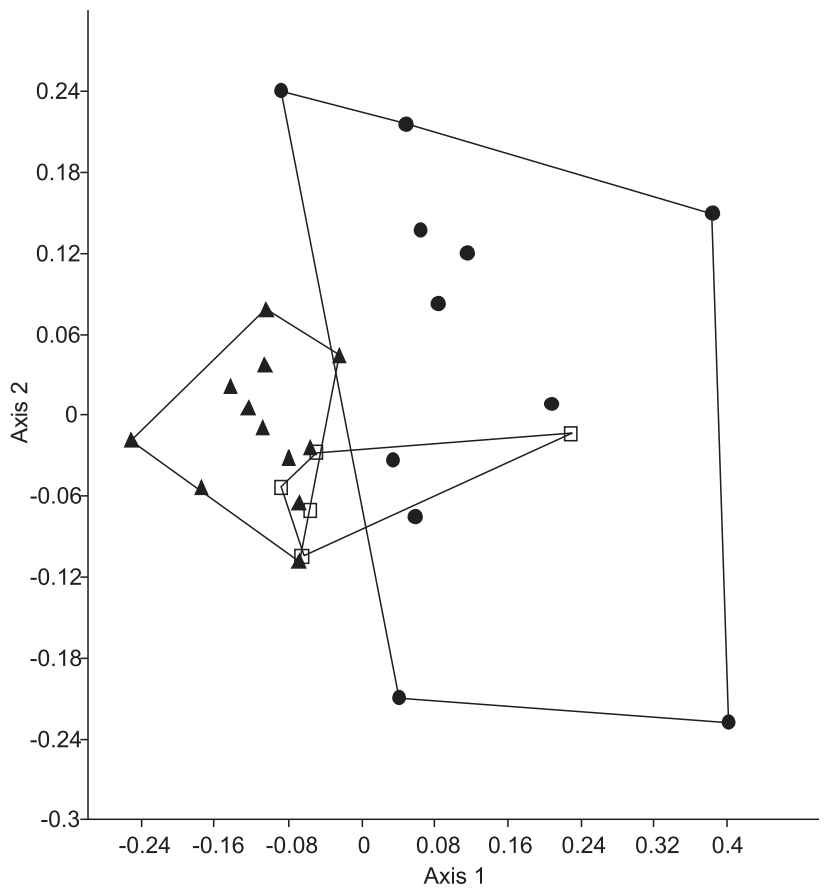

Figure 4. Non-Metric Multidimensional Scaling plot of faunal similarity among sites in three vegetation types in an Atlantic Forest area based on the Bray-Curtis index. Circles indicate grassland sites, triangles indicate forest sites, and squares indicate edge sites.

\section{DISCUSSION}

The total of 121 species of tiger moths found in our study represents approximately $40 \%$ of the total recorded from Rio Grande do Sul (Biezanko 1983, 1985, Teston \& Corseuil 2002, 2003a, b, Ferro \& Teston 2009), 10\% of the total species number from the Brazilian Atlantic Forest (Ferro \& Melo 2011), and $8.7 \%$ of the total known from Brazil (Ferro \& Diniz 2010). The tiger moth richness (considered as number of species) observed in our study was lower than those found in Boracéia, another Atlantic Forest site $\left(237\right.$ species, latitude $=23^{\circ} \mathrm{S}$, altitude $=800$ m) (Ferro \& Diniz 2007a); and in a montane cloud forest in Ecuador (287 species, latitude $=3^{\circ} \mathrm{S}$, altitude $=1,800-2,800 \mathrm{~m}$ ) (Hilt \& Fiedler 2005). However, our study area is at a higher altitude $(1,200 \mathrm{~m})$ and latitude $\left(28.7^{\circ} \mathrm{S}\right)$, and the annual temperature varies more widely than at Boracéia; and the latitude is higher than that of the Ecuadorian site.

Most of the species collected belong to Arctiinae. This was expected, because this subfamily is markedly more diverse in the Neotropical Region (4,761 species) than is Lithosiinae (1,170 species) (Heppner 1991). The Arctiinae richness at São José dos Ausentes represents almost 30\% of the total number of species of Arctiinae recorded from Rio Grande do Sul (TESTON \& Corseuil 2002, 2003a, b, Ferro \& Teston 2009). Thirty-one

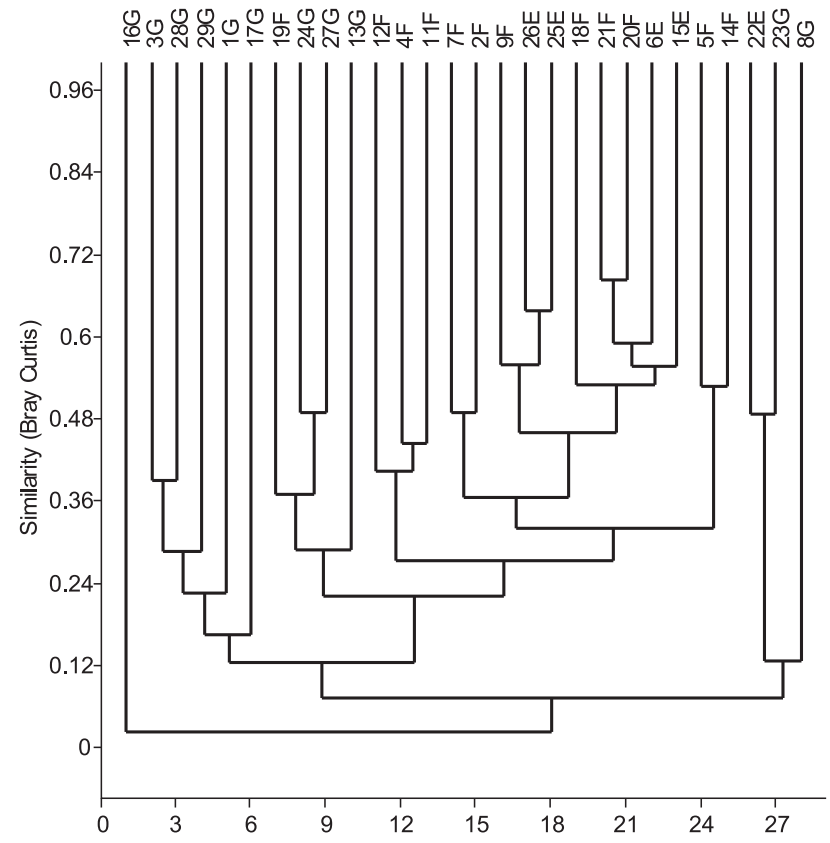

Figure 5. Unweighted Pair-Groups Method using arithmetic Averages plot of faunal similarity among sites in three vegetation types in an Atlantic Forest area, based on the Bray-Curtis index. (G) Grassland, (E) edge, (F) forest. For site numbers see Table I. Grassland site number 10 was excluded from the study because no moths were collected.

species of Lithosiinae were collected at São José dos Ausentes. BIEZANKo $(1983,1985)$ recorded an identical number of species in this subfamily for the entire state of Rio Grande do Sul.

No species occurred at all sites, and 40 species (33\%) were collected only at a single site. Similarly high proportions of rare species have also been observed for herbivorous insects (Novotny \& Basset 2000), moths (CAMARgo \& BeCKer 1999), and larvae of Lepidoptera (MARQUis et al. 2002).

The mean proportion of singletons was significantly higher in the grassland than in the edge and forest. Previous studies have reported a high proportion of moth singletons in forest habitats (Willot 1999, RicketTs et al. 2001, ВRehm et al. 2003, Hilt \& Fiedler 2005, Hilt et al. 2006). We suggest that the relatively low density of individuals in the grassland is the most probable factor accounting for the observation of a higher proportion of singletons in this habitat.

The rarefaction curves showed that the grassland fauna was richer than those of the other two habitats. This result contradicted what we expected. According to the habitat heterogeneity hypothesis (BAZZAz 1975), more complex habitats have more niches, and thus, increased diversity. More complex habitats generally provide a greater diversity of food resources, more stable microclimate, higher humidity, and larger numbers and kinds of refuges against predators (VAlLejo et al. 
1987). We expected to find the highest richness in the forest, which is a more heterogeneous habitat (greater range of vegetation height and light incidence, for example) than the grassland. Several studies have found a positive relationship between habitat heterogeneity and animal diversity (HADDAD et al. 2001, Poulsen 2002, Williams et al. 2002, Brose 2003, Tews et al. 2004, LASSAU et al. 2005). To our knowledge, this is the first study that observed a higher arthropod diversity in a grassland than in a forest habitat. For example, BALDISSERA et al. (2004) found that the richness of spiders was $150 \%$ lower in a grassland habitat than at the edge and inside an araucaria forest, and HiLt et al. (2006) recorded the lowest geometrid moth diversity at sites without woody vegetation. For microarthropods, MENTA et al. (2011) recorded a higher Shannon-Weiner diversity index in woodland than in grassland.

There are three possible explanations for the relatively high number of moth species found in the grassland. The first is the spatial distribution of food resources for larvae and adults. Larvae of many species of Arctiinae (74\% of the species recorded in this study) feed on plants of Asteraceae, Poaceae, and Fabaceae (Diniz et al. 2001), and the flowers of Asteraceae are often much visited by adults of Lepidoptera (BRown JR 1992). These three plant families are the most diverse in the southern Brazilian grasslands (BoldRINI 1997). In addition, many species of Arctiinae feed on herbaceous plants (SCOBLE 1992), which are more abundant in open habitats than in dense woodlands. Larvae of Lithosiinae mainly use lichens as host plants (SCOBLE 1992). Lichens were abundant on the trunks of Araucaria angustifolia (Bertol.) Kuntze trees in the forest habitat, and also occur, though at lower frequencies, on rocks in the grassland habitat (BoldRini et al. 2008). In fact, the fauna of Lithosiinae was less diverse in the grassland (only 95 individuals and 19 species) than in the forest (783 individuals and 25 species).

The second explanation is the usually erroneous idea that grassland has homogeneous vegetation. BoldRINI (1997) described six physiognomic regions of grassland vegetation in Rio Grande do Sul, considering local floristic variations associated with climate, topographic variation, and soil heterogeneity. Moreover, the grassland flora in southern Brazil is rich, with estimates ranging from 3,000 to 4,000 species (Overbeck et al. 2007), and several studies have found a positive relationship between plant and animal diversity (e.g., RoBInson \& Tuck 1993).

The last reason for the relatively high richness found in the grassland habitat may be the occurrence of tourist species. However, the sampling design used in this study attempted to minimize the attraction of moths from neighboring sites (use of a low-intensity light source, and sites separated by at least $200 \mathrm{~m})$. Furthermore, several species were collected only in the grassland, and few grassland species were shared with the forest and the edge. This pattern does not support the explanation of tourist species.

Both the NMDS and UPGMA analyses showed that the forest and edge faunas were similar to each other, and that the grassland fauna was a distinct group. Several other studies have also described a typical grassland fauna. Ferro \& Diniz (2007b) observed that the grassland arctiid assemblage differed from the assemblages in the vegetation types that contain trees, in the Brazilian Cerrado biome. A similar pattern was recorded for Ecuadorian arctiid (Hilt \& Fiedler 2005) and geometrid (Hilt et al. 2006) moths, and for Indonesian dung beetles (SHAHABUdDiN et al. 2010). The NMDS analysis also indicated that the similarity among the grassland sites was lower than among the edge/ forest sites. The fewer individuals sampled (and high number of singletons) in this habitat probably influenced the estimate of lower similarity among the grassland sites.

All multivariate analyses suggested that the habitat type and the spatial proximity between the sites explained the observed beta diversity pattern. STEINITZ et al. (2006) also observed a positive correlation between bird and slug faunas, and environmental and geographical distances. However, the study area sampled by STEINITZ et al. (2006) had much larger environmental (e.g., precipitation ranging from 32 to $1,238 \mathrm{~mm}$ ) and geographical (e.g., from about $10 \mathrm{~km}$ to more than $300 \mathrm{~km}$ ) distances than in our study. This suggests that tiger moths respond to small habitat changes, because within a small range of variation in habitat and geographical distances (the difference in altitudes between the sites was only $123 \mathrm{~m}$, and the longest geographical distance between the sites was $21.5 \mathrm{~km}$ ), it was possible to observe statistical differences among the assemblages of the sampling sites. These results reinforce the importance of these moths as a bioindicator group (KITCHING et al. 2000, Summerville et al. 2004, Hilt \& Fiedler 2005).

This study provided the first records of 22 species (18.2\%) from Rio Grande do Sul. This proportion is particularly high for Arctiidae. Teston \& CoRseuil (2004), for example, reported that only $1.5 \%$ of the records for tiger moths in six localities of the Atlantic Forest in Rio Grande do Sul were new. In addition, the possibilities that some of the 30 undetermined tiger moth species have not yet been described, and that a large number of species remain to be found (a minimum of 59 additional species, according to the second-order Jackknife) also emphasize the importance of the study area. The fauna of the region has a relatively high number of endemic species (BOND-BuckuP 2008); and the region is home to many species of endangered birds, including globally endangered species (Fontana et al. 2008). In spite of the considerable biological importance of this region, faunal studies are few, particularly for invertebrates.

The results presented here demonstrate that the grassland vegetation supports an exclusive and rich tiger moth fauna, reinforcing the importance of continued scientific investigations and of conservation of this type of vegetation. The protection of grassland ecosystems is much neglected, considering the many threats to their diversity. Less than $0.5 \%$ of the southern Brazilian grassland is legally protected as part of conservation units (Overbeck et al. 2007). The introduction of exotic species (such as trout, grasses, and trees) has strongly impacted 
the native biota, and poses a serious threat to the conservation of diversity in the region (OvERBECK et al. 2007, Bond-Buckup 2008). Additional studies of the impact of exotic species on the fauna and flora of this region are urgently needed. These investigations will form a basis for conservation planning and for the future creation of conservation units in this region.

\section{ACKNOWLEDGEMENTS}

We especially thank Adriano S. Melo for his help in the field sampling. We are indebted to farm administrators for allowing VGF access to collect the moths, and to the Associação Sócio-Ambientalista Igré, particularly to Georgina Bond-Buckup, for permission to use the research base in São José dos Ausentes. VGF received a post-doctoral fellowship from the Conselho Nacional de Desenvolvimento Científico e Tecnológico (CNPq) (proc. 155533/2006-1). HPR received research funding from CNPq (472175/2007-6; 308292/2007-3).

\section{LITERATURE CITED}

Baldissera, R.; G. Ganade \& S.B. Fontoura. 2004. Web spider community response along an edge between pasture and Araucaria Forest. Biological Conservation 118: 403-409.

BAZZAZ, F.A. 1975. Plant species diversity in old-field successional ecosystems in southern Illinois. Ecology 56: 485-488.

Biezanko, C.M. 1983. Ctenuchidae, Nolidae, Arctiidae et Pericopidae da Zona Sudeste do Rio Grande do Sul. Revista do Centro de Ciências Rurais 13: 229-263.

Bizzanko, C.M. 1985. Ctenuchidae, Arctiidae et Pericopidae da Zona Missioneira do Rio Grande do Sul. Revista do Centro de Ciências Rurais 15: 189-210.

Boldrini, I.I. 1997. Campos do Rio Grande do Sul: Caracterização fisionômica e Problemática Ocupacional. Boletim do Instituto de Biociências 56: 1.

Boldrini, I.I.; H.M. Longhi-Wagner \& L. Eggers. 2008. Flora, p. 38-57. In: G. Bond-Buckup (Ed.). Biodiversidade dos Campos de Cima da Serra. Porto Alegre, Libretos, 196p.

Bond-Buckup, G. 2008. Biodiversidade dos Campos de Cima da Serra. Porto Alegre, Libretos, 196p.

BRehm, G.; D. Süssenback \& K. Fiedler. 2003. Unique elevational diversity patterns of geometrid moths in an Andean montane rainforest. Ecography 26: 456-466.

BRose, U. 2003. Bottom-up control of carabid beetle communities in early successional wetlands mediated by vegetation structure or plant diversity? Oecologia 135: 407-413.

BRown JR, K.S. 1992. Borboletas da Serra do Japi: diversidade, hábitats, recursos alimentares e variação temporal, p. 142187. In: L.P. Morellato (Ed.). História natural da Serra do Japi: ecologia e preservação de uma área florestal no sudeste do Brasil. São Paulo, Unicamp, 321p.

Brown Jr, K.S. \& A.V.L. Freitas. 1999. Lepidoptera, p. 225-243. In: C.R.F. BRandão \& E.M. Cancello (Eds). Biodiversidade do Estado de São Paulo: síntese do conhecimento ao final do século XX. 5. Invertebrados terrestres. São Paulo, Fapesp, 279p.

Camargo, A.J.A. \& V.O. Becker. 1999. Saturniidae (Lepidoptera) from the Brazilian Cerrado: composition and biogeographic relationships. Biotropica 31: 696-705.

Departamento Nacional de Meteorologia. 1992. Normais climatológicas (1961-1990). Brasília, Ministério da Agricultura, 84p.

Diniz, I.R.; H.C. Morais \& A.J.A. Camargo. 2001. Host plants of lepidopteran caterpillars in the cerrado of the Distrito Federal, Brazil. Revista Brasileira de Entomologia 45: 107-122.

Ferro, V.G. \& A.S. Melo. 2011. Diversity of tiger moths in a Neotropical hotspot: determinants of species composition and identification of biogeographic units. Journal of Insect Conservation 15: 643-651.

FerRo, V.G. \& I.R. Diniz. 2007a. Arctiidae (Insecta: Lepidoptera) da Estação Biológica de Boracéia (Salesópolis, São Paulo, Brasil). Available online at: http://www.biotaneotropica.org.br/ v7n3/pt/fullpaper?bn03107032007+pt [Accessed: 9/III/2011].

Ferro, V.G. \& I.R. Dinız. 2007b. Composição de espécies de Arctiidae (Insecta, Lepidoptera) em áreas de Cerrado. Revista Brasileira de Zoologia 24: 635-646.

FerRo, V.G. \& I.R. Dinız. 2010. Riqueza e composição das mariposas Arctiidae (Lepidoptera) no Cerrado, p. 255-313. In: I.R. DINIZ, J. Marinho Filho, R.B. Machado \& R.B. Cavalcanti (Eds). Cerrado: conhecimento científico quantitativo como subsídio para ações de conservação. Brasília, Thesaurus Editora, 516p. Ferro, V.G. \& J.A. Teston. 2009. Composição de espécies de Arctiidae (Lepidoptera) no sul do Brasil: relação entre tipos de vegetação e entre a configuração espacial do habitat. Revista Brasileira de Entomologia 53: 278-286.

Fontana, C.S.; M. Repenning; C.E. RovedDer \& M.L. Gonçalves. 2008. Aves, p. 118-135. In: G. Bond-Buckup (Ed.). Biodiversidade dos Campos de Cima da Serra. Porto Alegre, Libretos, 196p.

Haddad, N.M.; D. Tilman; J. HaArstad, M. Ritchie \& J.M.H. Knops. 2001. Contrasting effects of plant richness and composition on insect communities: a field experiment. American Naturalist 158: 17-35.

Hammer, Ø.; D.A.T. Harper \& P.D. Ryan. 2007. PAST - Palaeontological Statistics. Available online at: http://folk.uio.no/ ohammer/past [Accessed: 9/III/2011].

Hampson, G.F. 1898. Catalogue of the Lepidoptera Phalaenae in the British Museum. Volume 1. London, Printed by order of the Trustees of the British Museum, 559p.

Hampson, G. F. 1900. Catalogue of the Lepidoptera Phalaenae in the British Museum. Volume 2. London, Printed by order of the Trustees of the British Museum, 589p.

Hampson, G. F. 1901. Catalogue of the Lepidoptera Phalaenae in the British Museum. Volume 3. London, Printed by order of the Trustees of the British Museum, 690p.

Hampson, G. F. 1914. Catalogue of the Lepidoptera Phalaenae in the British Museum. Supplement 1. London, Printed by order of the Trustees of the British Museum, 858p. 
Heppner, J.B. 1991. Faunal regions and the diversity of Lepidoptera. Tropical Lepidoptera 2: 1-85.

Hilt, N. \& K. Fiedler. 2005. Diversity and composition of Arctiidae moth ensembles along a successional gradient in the Ecuadorian Andes. Diversity and Distributions 11: 387-398.

Hitt, N. \& K. Fiedler. 2006. Arctiid moth ensembles along a successional gradient in the Ecuadorian montane rain forest zone: how different are subfamilies and tribes? Journal of Biogeography 33: 108-120.

Hilt, N.; G. Brehm \& K. Fiedler. 2006. Diversity and ensemble composition of geometrid moths along a successional gradient in the Ecuadorian Andes. Journal of Tropical Ecology 22: 155-166.

Jacobson, N.L. \& S.J. Weller. 2002. A cladistic study of the Arctiidae (Lepidoptera) by using characters of immatures and adults. Lanham, Entomological Society of America, Thomas Say Publication in Entomology: Monographs, 98p.

Kitching, R.L.; A.G. Orr; L. Thalib; H. Mitchell; M.S. Hopkins \& A.W. Graham. 2000. Moth assemblages as indicators of environmental quality in remnants of upland Australian rain forest. Journal of Applied Ecology 37: 284-297.

Lassau, S.A.; D.F. Hochuli; G. Cassis \& C.A.M. Reid. 2005. Effects of habitat complexity on forest beetle diversity: do functional groups respond consistently? Diversity and Distributions 11: 73-82.

Legendre, P.; D. Borcard \& P.R. Peres-Neto. 2005. Analysing beta diversity: partitioning the spatial variation of community composition data. Ecological Monographs 75: 435-450.

MARQUIS, R.J.; H.C. MoraIs \& I.R. DinIZ. 2002. Interactions among cerrado plants and their herbivores: unique or typical? $\mathrm{p}$. 306-328. In: P.S. Oliveira \& R.J. Marquis (Eds). The Cerrados of Brazil: Ecology and Natural History of a Neotropical Savanna. New York, Columbia University Press, 398p.

Menta, C.; A. Leoni; C. Gardi \& F.D. Conti. 2011. Are grasslands important habitats for soil microarthropod conservation? Biodiversity and Conservation. DOI 10.1007/s10531-0110017-0

Morelato, L.P.C. \& C.F.B. Haddad. 2000. The Brazilian Atlantic Forest: An Introduction. Biotropica 32: 786-792.

Muirhead-Thompson, R.C. 1991. Trap responses of flying insects. London, Academic Press, 304p.

Myers, N.; R.A. Mittermeier; C.G. Mittermeier; G.A.B. Fonseca \& J. Kent. 2000. Biodiversity hotspots for conservation priorities. Nature 403: 853-858.

Novotny, V. \& Y. BASSET. 2000. Rare species in communities of tropical insect herbivores: pondering the mystery of singletons. Oikos 89: 564-572.

Oliveira-Filho, A.T. \& M.A.L. Fontes. 2000. Patterns of floristic differentiation among Atlantic Forests in southeastern Brazil and the influence of climate. Biotropica 32: 793-810.

Overbeck, G.E.; S.C. Muller; S. Fidelis; J. Pfadenhauer; V.P. Pillar; C.C. Blanco; I.I. BoldRini; R. Both \& E. FoRneCK. 2007. Brazil's neglected biome: the South Brazilian Campos. Perspectives in Plant Ecology, Evolution and Systematics 9: 101-116. Piñas Rubio, F.S.J.; S. RaAb-Green; G. Onore \& I. Manzano. 2000. Mariposas del Ecuador. Familia Arctiidae. Quito, Pontificia Universidad Católica del Ecuador, vol. 20, 84p.

Piñas Rubio, F.S.J. \& I. Manzano. 2003. Mariposas del Ecuador. Arctiidae, subfamilia Ctenuchinae. Quito, Compañia de Jesús, vol. 21b, 95p.

Poulsen, B.O. 2002. Avian richness and abundance in temperate Danish forests: tree variables important to birds and their conservation. Biodiversity and Conservation 11: 15511566.

Ricketts, T.H.; G.C. Daily; P.R. Ehrlich \& J.P. Fay. 2001. Countryside biogeography of moths in a fragmented landscape: biodiversity in native and agricultural habitats. Conservation Biology 15: 378-388.

Robinson, G.S. \& K.R. Tuck. 1993. Diversity and faunistics of small moths (microlepidoptera) in Bornean rainforest. Ecological Entomology 18: 385-393.

Scoble, M.J. 1992. The Lepidoptera: Form, Function and Diversity. New York, Oxford University Press, 404p.

Shahabuddin, P.H.; M. SJafrida; A.N. Woro; T. TscharntKe \& C.H. Schulze. 2010. Diversity and body size of dung beetles attracted to different dung types along a tropical land-use gradient in Sulawesi, Indonesia. Journal of Tropical Ecology 26: 53-65.

Steinitz, O.; J. Heller; A. Tsoar; D. Rotem \& R. Kadmon. 2006. Environment, dispersal and patterns of species similarity. Journal of Biogeography 33: 1044-1054.

Summerville, K.S.; L.M. RitTer \& T.O. Crist. 2004. Forest moth taxa as indicators of lepidopteran richness and habitat disturbance: a preliminary assessment. Biological Conservation 116: 918.

SYSTAT 9. 1998. Statistics I - Manual. Chicago, SPSS Inc.

Tabarelli, M.; L.P. Pinto; J.M.C. Silva \& M. Нirot. 2005. Challenges and opportunities for biodiversity conservation in the Brazilian Atlantic Forest. Conservation Biology 19: 695-700.

Teston, J.A. \& E. Corseuil. 2002. Arctiinae (Lepidoptera, Arctiidae) ocorrentes no Rio Grande do Sul, Brasil. Parte I. Pericopini. Biociências 10: 261-268.

Teston, J.A. \& E. Conseull. 2003a. Arctiinae (Lepidoptera, Arctiidae) ocorrentes no Rio Grande do Sul, Brasil. Parte II. Arctiini, Callimorphini e Phaegopterini. Biociências 11: 69-80.

Teston, J.A. \& E. Corseuil. 2003b. Arctiinae (Lepidoptera, Arctiidae) ocorrentes no Rio Grande do Sul, Brasil. Parte III. Ctenuchini e Euchromiini. Biociências 11: 81-90.

Teston, J.A. \& E. Conseuil. 2004. Diversidade de Arctiinae (Lepidoptera, Arctiidae) capturados com armadilha luminosa, em seis comunidades no Rio Grande do Sul, Brasil. Revista Brasileira de Entomologia 48: 77-90.

Tews, J.; U. Brose; V. Grimm; K. Tielborger; M.C. Wichmann; M. SchWager \& F. Jeltsch. 2004. Animal species diversity driven by habitat heterogeneity/diversity: the importance of keystone structures. Journal of Biogeography 31: 79-92. 
Vallejo, L.R.; C.L. Fonseca \& D.R.P. Gonçalves. 1987. Estudo comparativo da mesofauna do solo em áreas de Eucalyptus citriodora e mata secundária heterogênea. Revista Brasileira de Biologia 47: 363-370.

Watson, A. \& D.T. Goodger. 1986. Catalogue of the Neotropical tiger-moths. Occasional Papers on Systematic Entomology 1: 1-71.

Williams, S.E.; H. Marsh \& J. WinTer. 2002. Spatial scale, species diversity, and habitat structure: small mammals in Australian tropical rain forest. Ecology 83: 1317-1329.

WiLlot, S.J. 1999. The effects of selective logging on the distribution of moths in a Bornean rainforest. Philosophical Transactions of the Royal Society of London (B), Biological Sciences 354: 1783-1790.

Yela, J.L. \& M. Holyoak. 1997. Effects of moonlight and meteorological factors on light and bait trap catches of noctuid moths (Lepidoptera: Noctuidae). Environmental Entomology 26: 1283-1290.

Submitted: 10.V.2011; Accepted: 08.XII.2011.

Editorial responsibility: Gabriel L.F. Mejdalani 